\title{
Evaluating Desert Actinomycetes for Enzyme and Antibacterial Production
}

\author{
Abdulrahman A.M. Alghamdi' ${ }^{1 *}$, Tamer S. Abdelmoneim ${ }^{1,2}(\mathbb{D})$, \\ Naif Kadasa ${ }^{1}$ and Yaaser Q. Almulaiky,4 \\ ${ }^{1}$ Department of Biology, Faculty of Science, University of Jeddah, 21959 Jeddah, Saudi Arabia. \\ ${ }^{2}$ Department of Botany, Faculty of agriculture, Suez Canal University, Ismailia, Egypt. \\ ${ }^{3}$ Department of Chemistry, College of Sciences and Arts at Khulis, University of Jeddah, Jeddah, Saudi Arabia. \\ ${ }^{4}$ Department of Chemistry, Faculty of Applied Science, Taiz University, Yemen.
}

\begin{abstract}
A total of 13 Actinomycetes strains were isolated from $\mathbf{7 0}$ soil samples collected from five locations across the Jeddah Province, while the other two locations located in Baljurashi province of Saudi Arabia. All 13 isolates were purified and subjected to enzymatic screening and antibacterial assays. The results indicated that two of these isolates (AC45 and AC69) produced both enzymes and exerted some antibacterial activity. Isolate $A C 45$ produced more amylase and polygalacturonase (697.8 and 1498.59 units $/ \mathrm{ml}$, respectively) than isolate AC69; however, AC69 secreted more lipase than AC45 ( 6957 and 22127 unit/ml, respectively). Furthermore, both AC45 and AC69 exhibited good antibacterial activity against Staphylococcus aureus, Staphylococcus epidermidis, and Bacillus subtilis. The two isolates were identified using their 16S rRNA sequences, and the results suggest that isolate AC45 shares $99.71 \%$ similarity with Streptomyces lavenduligriseus and isolate AC69 shares $99 \%$ similarity with Streptomyces sp.
\end{abstract}

Keywords: Antibacterial, Actinomycetes, Amylase, Polygalacturonase, Lipase

*Correspondence: a-alghamdi94@hotmail.com

(Received: December 21, 2020; accepted: May 05, 2021)

Citation: Alghamdi AAM, Abdelmoneim TS, Kadasa N, Almulaiky YQ. Evaluating Desert Actinomycetes for Enzyme and Antibacterial Production. J Pure Appl Microbiol. 2021;15(2):976-982. doi: 10.22207/JPAM.15.2.56

(C) The Author(s) 2021. Open Access. This article is distributed under the terms of the Creative Commons Attribution 4.0 International License which permits unrestricted use, sharing, distribution, and reproduction in any medium, provided you give appropriate credit to the original author(s) and the source, provide a link to the Creative Commons license, and indicate if changes were made. 


\section{INTRODUCTION}

Actinomycetes are filamentous grampositive bacteria ${ }^{1}$, which produce hyphae ${ }^{2}$ and are characterized by the production of conidia ${ }^{3}$. They also have a high G-C content, at over $55 \%$ of their $\mathrm{DNA}^{3,4}$, are unicellular ${ }^{2}$ and non-motile ${ }^{1}$. The Actinobacteria phylum is one of the largest taxonomic units within the bacterial domain ${ }^{5,6}$ with its constituents widely distributed across different environments ${ }^{7-9}$, including some extreme habitats ${ }^{10}$. Despite this, soil remains the most significant habitat for Actinomycetes species².

Actinobacteria have the ability to produce various natural bioactive products ${ }^{10}$, which are both economically and biologically valuable, including enzymes, antibiotics, antitumor, and immune regulatory agents ${ }^{11-13}$. In fact, two-thirds of the world's most common antibiotics are synthesized by Actinobacteria ${ }^{14}$, with most of these products produced by the members of the Streptomyces genus 4 .

Various studies have reported that some genera of the Actinomycetes produce a diverse range of enzymes that can be applied in biotechnology driven industries and bio microbial applications ${ }^{15}$. In 1940, the first Actinomycete derived antibiotic (Actinomycin) with bacteriostatic and bactericidal properties was purified from Streptomyces antibioticus (formerly known as Actinomyces antibioticus) $)^{16-20}$.

With the spread of resistance of certain microbes to antibiotics, the need to discover new antibiotics is increasing. Actinomycete is one of the possible ways to increase the chance of finding new and interesting antibiotics due to their diversity.

The searching for a new site, such as the deserts to take soil samples and isolate some of the Actinomycetes for the studying of secondary metabolites, which can be detected for some of the reliable materials in the field of resistance to pathogenic bacteria rather than the most common types of Streptomyces found in soil samples around the world ${ }^{21} 22$.

Here we isolated a series of Actinomycete strains from the desert soil from five locations in Saudi Arabia. These isolates were evaluated for their enzyme ( $\alpha$-amylase, polygalacturonase, and lipase) production and antimicrobial activity against several known pathogens. Identification of the selected isolates was performed using their 16S rRNA sequences.

\section{MATERIALS AND METHODS \\ Sample collection}

A total of 70 soil samples were collected from five different locations across Saudi Arabia including three sites in the Jeddah Province and two sites in the Baljurashi province (Table1). Samples were collected at a depth of $15 \mathrm{~cm}$ using a shovel and stored in sterile polyethylene bags. The samples were then transported to the laboratory for further isolation, where remained until dryness in room temperate for three days.

\section{Isolation of Actinomycetes}

Actinomycetes were isolated using the soil dilution plate technique ${ }^{23}$ and Starch-Casein agar (SCA) plates ${ }^{24}$. Briefly, one gram of soil sample was suspended in $10 \mathrm{ml}$ of distilled water and then diluted up to $10^{-5}$ " dilutions ${ }^{4}$. Then, $100 \mu \mathrm{l}$ of each dilution was spread on the SCA medium and incubated at $28^{\circ} \mathrm{C}$ for $7-15$ days.

\section{Screening for enzymes production}

Three types of enzymes were evaluated in this study, the assay for each is described below. $\alpha$-Amylase

$\alpha$-Amylase activity was determined by measuring the amount of maltose released from a starch substrate following addition to the growth media ${ }^{25}$. The absorbance was recorded at $560 \mathrm{~nm}$ using a spectrophotometer (Jenway 6305 UV/Visible Spectrophotometer) and one unit of enzyme activity was defined as the amount of enzyme producing $1 \mu \mathrm{mol}$ of reducing sugar as maltose per hour under standard assay conditions.

\section{Polygalacturonase}

Polygalacturonase activity was assayed using polygalacturonic acid as a substrate ${ }^{26}$. The absorbance was measured at $560 \mathrm{~nm}$ using a spectrophotometer (Jenway 6305 UV/Visible

Table 1. Locations of the samples

\begin{tabular}{|c|c|c|c|}
\hline Location & & $\begin{array}{l}\text { GPS } \\
\text { reading }\end{array}$ & $\begin{array}{c}\text { No. of } \\
\text { samples }\end{array}$ \\
\hline \multirow[t]{3}{*}{ Jeddah } & 1 & N $21^{\circ} 50^{\prime} 22.5$ E $39^{\circ} 08^{\prime} 12.7$ & 20 \\
\hline & 2 & N $21^{\circ} 54^{\prime} 15.3$ E $39^{\circ} 21^{\prime} 04.9$ & 13 \\
\hline & 3 & N $21^{\circ} 53^{\prime} 36.1$ E $39^{\circ} 21^{\prime} 00.9$ & 12 \\
\hline \multirow[t]{2}{*}{ Baljurashi } & 4 & 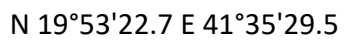 & 14 \\
\hline & 5 & N $19^{\circ} 53^{\prime} 32.0$ E $41^{\circ} 35^{\prime} 31.5$ & 11 \\
\hline
\end{tabular}


Spectrophotometer) and one unit of enzyme activity was defined as the amount of enzyme that liberated 1 imol of galacturonic acid per minute under standard assay conditions.

Lipase

Lipase activity was assayed using the Winkler and Stuckmann spectrophotometric assay ${ }^{27}$. The absorbance of the released p-nitrophenol was recorded at $410 \mathrm{~nm}$ using a spectrophotometer (Jenway 6305 UV/Visible Spectrophotometer).

\section{Extraction of the secondary metabolites}

Two isolates were selected to fermented in liquid medium (starch-casein) in shaking incubator on $180 \mathrm{rpm}$ at $30^{\circ} \mathrm{C}$ for 7 days. The mycelia were collected and added to methanol in ratio of $1: 1(\mathrm{v} / \mathrm{v})$, and shaking it overnight, after that, the methanol extract was evaporated in a rotary evaporated until dryness. The culture filtrate $(200 \mathrm{ml})$ was extracted by adding ethyl acetate as a solvent where were added to the in the ratio of $1: 1(v / v)$. followed by shaken vigorously for 10 minutes. The ethyl acetate phase was separated from the aqueous phase using separating funnel then evaporated in a rotary evaporated until dryness.

\section{Screening for Antimicrobial Activities}

The antimicrobial activity of the selected Actinomycetes isolates was screened using two pathogenic bacteria (Staphylococcus aureus ATCC 6538 and Staphylococcus epidermidis ATCC 12228) and one Bacillus subtilis isolated obtained from King Abdul Aziz Hospital in Jeddah, Saudi Arabia. Antimicrobial efficacy was determined using the agar-well diffusion method, where $6 \mathrm{~mm}$ diameter wells were created in the agar media and then filled with the antimicrobial extract ${ }^{28}$.

Mueller Hinton agar plates were prepared and inoculated with the bacteria of interest and allowed to grow to a lawn culture before the wells were filled with the extract of interest. The plates were then cooled at $4{ }^{\circ} \mathrm{C}$ for 30 seconds and then incubated at $37{ }^{\circ} \mathrm{C}$ for $24 \mathrm{~h}$. Microbial inhibition was observed as zones of clearance which were then measured and recorded.

\section{Isolate identification}

The DNA from each isolate was extracted and sent to macrogene, in Seoul, Republic of Korea where it underwent 16S rRNA sequencing. These sequences were then compared to the 16S rRNA sequences in the NCBI GenBank database using the basic alignment search tool (BLAST) ${ }^{29}$.

\section{RESULT}

A total of 13 Actinomycetes were isolated from 70 soil samples collected from five different locations across Saudi Arabia. Among the isolates, two strains (AC 45 and AC 69) demonstrated both enzyme production and antimicrobial activity against at least one of the bacterial pathogens used in the preliminary screening. BLAST analysis of the 16S rRNA gene sequences from these soil Actinomycetes isolates revealed that AC45 shared 99.71\% sequence similarity with Streptomyces lavenduligriseus and AC69 shared 99\% sequence similarity with Streptomyces sp. G49 These results are summarized in Table 2 and the morphological structure for each isolate is described in Fig. 1.

The two isolates were screened for production of a-amylase, polygalacturonase, and lipase, where the estimation of enzymes productivity are recorded as (unit/ml) Fig. 2.

The S. lavenduligriseus isolate was shown to produce more amylase and polygalacturonase than the Streptomyces sp isolate but the Streptomyces $\mathrm{sp}$ isolate secreted more lipase than the $S$. lavenduligriseus isolate.

The antimicrobial activities of the selected isolates were tested against several pathogenic strains, and antagonism was measured by determining the size of the zone of inhibition $(\mathrm{mm})$ for each (Figs. 3 and 4).

Table 2. List of BLAST results for the $16 \mathrm{~S}$ sequence

\begin{tabular}{lll}
\hline Isolate No. & Description & Accession \\
\hline AC 45 & $\begin{array}{l}\text { Streptomyces lavenduligriseus } \\
\text { strain NRRL ISP-5487 contig 85.1 }\end{array}$ & NZ_JOBD01000085.1 \\
AC 69 & $\begin{array}{l}\text { Streptomyces sp. G49 } \\
\text { KT741025.1 }\end{array}$
\end{tabular}



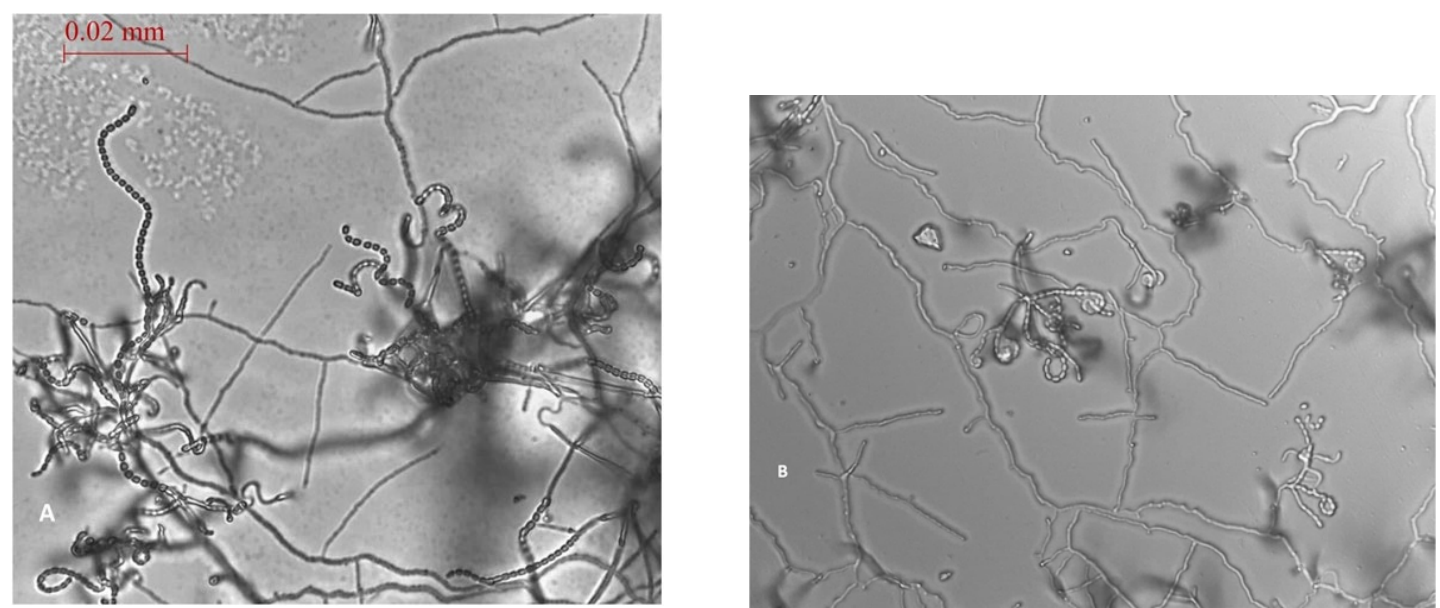

Fig. 1. Spore chain arrangement observed at 1000X. A) Isolate AC 45- Streptomyces lavenduligriseus, B) Isolate number AC 69 - Streptomyces sp.

The results, which illustrated in Figure 4 that showing the isolate of Actinomycetes Streptomyces sp. G49 which was recorded the best result for inhibition pathogenic bacterial growth in all treatments to $S$. aureas, S. epidermidis and B. subtilis, $(8,10,9 \mathrm{~mm})$ respectively, comparing with the results for using standard antibiotics, Gentamicin 120ug $(10,12,13 \mathrm{~mm})$, and Clindamycin 2 ug $(12,10$ and $10 \mathrm{~mm})$ respectively.

On the other hand, the isolate of $S$. lavenduligriseus outperformed on the both antibiotics to control of Bacillus subtilis, which recoded $9 \mathrm{~mm}$ (inhibition zone size) compared by 13 and $10 \mathrm{~mm}$ for both Gentamicin 120ug and Clindamycin 2ug, respectively.

\section{DISCUSSION}

This study successfully isolated two antibacterial producing Actinomycetes from Saudi desert soils. Among the 13 selected isolates, only two demonstrated the ability to produce antibacterial agents with activity against the tested microbes, and both AC45 (Streptomyces lavenduligriseus) and AC69 (Streptomyces sp.) showed good antibacterial activity against Bacillus subtilis, Staphylococcus aureus, and Staphylococcus epidermidis. These results were similar to the study conducted by Ganesan et $\mathrm{al}^{4}$, who screened 106 isolates from Nilgiris district soil in the Western Ghats of Tamil Nadu, India, and cross-streaked against various microbial pathogens, and found that 44 isolates
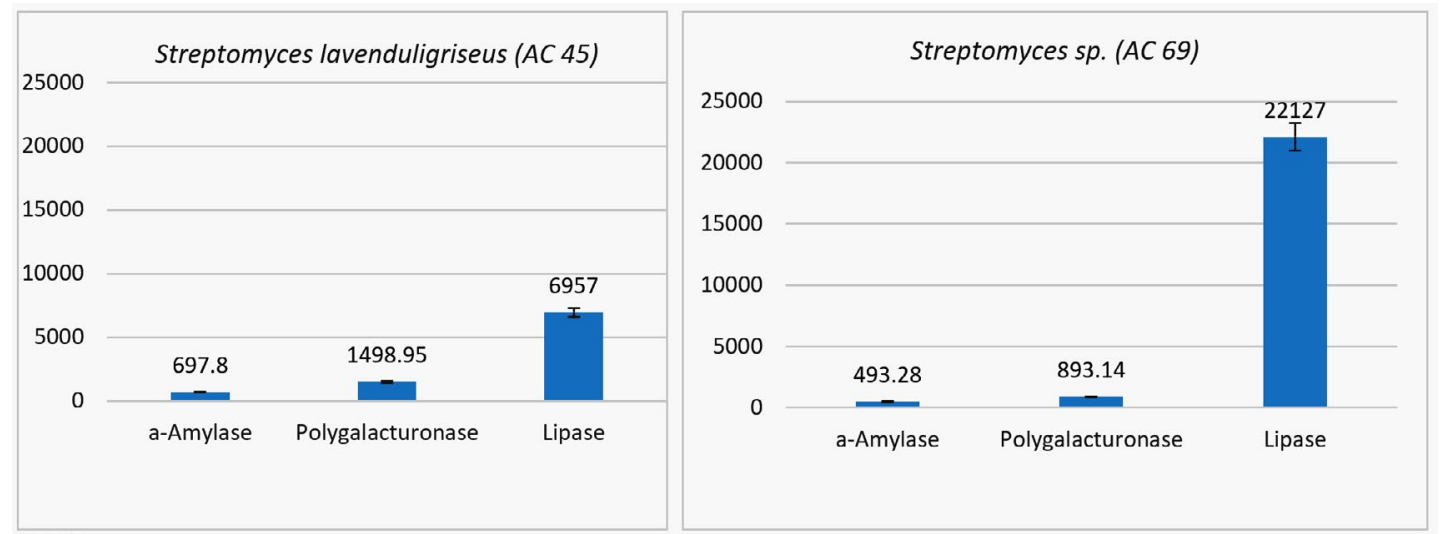

Fig. 2. The estimation of enzymes productivity (unit/ml) for two isolate of streptomyces (Streptomyces lavenduligriseus and Streptomyces sp.) 


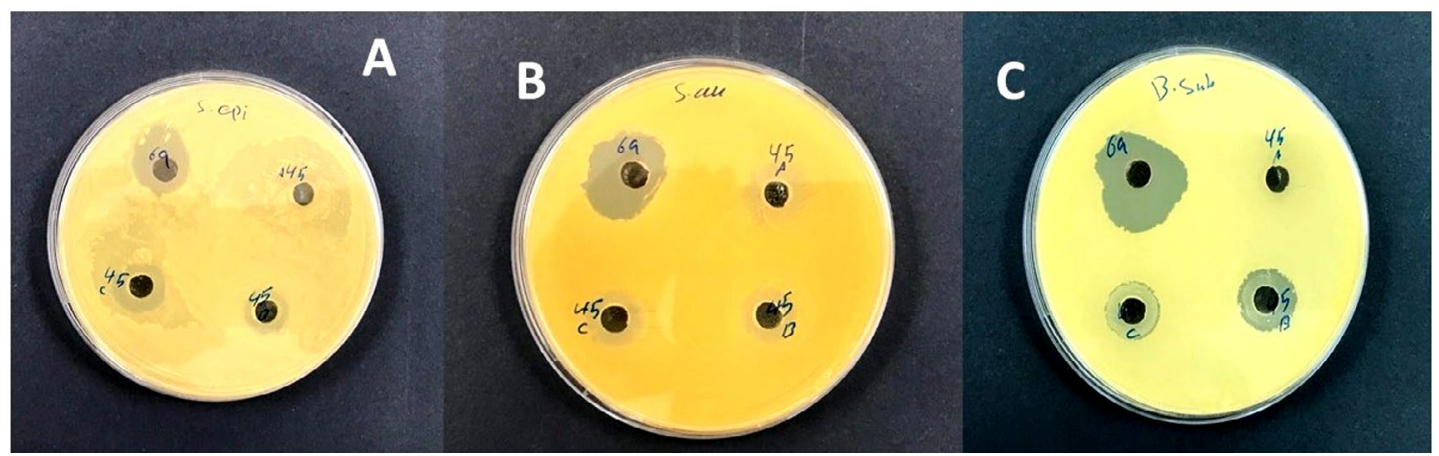

Fig. 3. A: Streptomyces lavenduligriseus (AC 45) was recorded a moderate effect against Staphylococcus epidermidis while Streptomyces sp.(AC 69) showed a good effect. B: isolate of Streptomyces sp. (AC 69) showed a strong effect against Staphylococcus aureus while isolate S. lavenduligriseus (AC 45) showed a moderate effect. C: the same result in B but in the presence of Bacillus subtilis.

\section{Inhibition Zone (mm)}

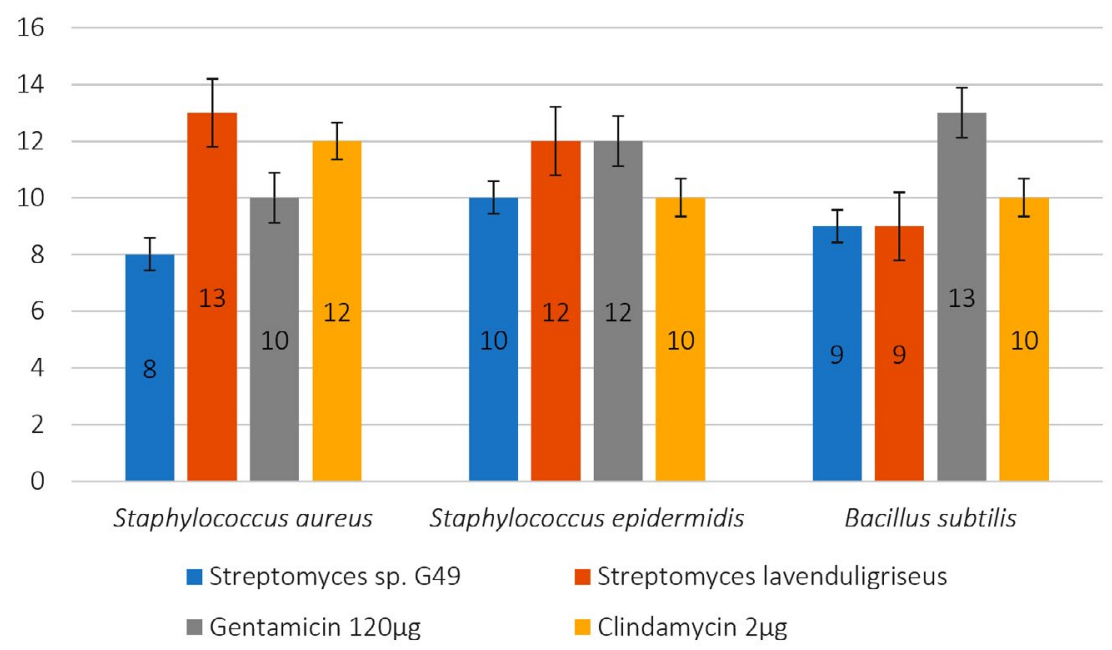

Fig. 4. Antagonistic activity of Actinomycetes isolates by $\mathrm{mm}$ against pathogens (Staphylococcus aureus ATCC 6538; Staphylococcus epidermidis ATCC 12228; Bacillus subtilis) with $125 \mu \mathrm{l}$ of extract comparing with two stander antibiotic Gentamicin 120 $\mathrm{g}$ and Clindamycin $2 \mu \mathrm{g}$.

exhibited good antimicrobial activity against different pathogenic microbes ${ }^{4}$. In addition, Mohamed et $\mathrm{al}^{30}$ isolated 32 Actinomycetes from Algerian desert soil, three of which showed antibacterial activity against $B$. cereus, S. aureus, and S. epidermidis. ${ }^{30}$

Both isolates were also evaluated for the production of $\alpha$-amylase and both isolates demonstrated good $\alpha$-amylase activity, which is in agreement with the study conducted by Yassien and Asfour ${ }^{31}$ who demonstrated the ability of five Streptomyces isolates to produce $\alpha$-amylase ${ }^{31}$. Our isolates also produce polygalacturonase and lipase, which is in agreement with the study conducted by Salehghamari et $\mathrm{al}^{32}$ on a Streptomyces coelicoflavus isolate from the Meyghan Salt Lake of Arak located in the Markazi Province of Iran, which produced polygalacturonase, and Cardenas et $\mathrm{al}^{33}$, who identified three novel lipases produced by Actinomycetes strains ${ }^{32,33}$. These results are also in agreement with Swarna and Gnanadoss ${ }^{34}$ who identified five lipases producing from Actinomycetes ${ }^{34}$.

In future studies, both enzymes and antimicrobials component will be extracted and purified with the aim of determining the chemical 
composition, to try to use it as anti-pathogenic materials as one of the attempts to find new types of natural antibiotics produced from desert Actinomycetes.

\section{ACKNOWLEDGMENTS}

None.

\section{CONFLICT OF INTEREST}

The authors declare that there is no conflict of interest.

\section{AUTHORS' CONTRIBUTION}

All authors listed have made a substantial, direct and intellectual contribution to the work, and approved it for publication.

\section{FUNDING}

None.

\section{DATA AVAILABILITY}

The datasets generated and/or analysed during the current study are available from the corresponding author on reasonable request.

\section{ETHICS STATEMENT}

This article does not contain any studies with human participants or animals performed by any of the authors.

\section{REFERENCES}

1. Sharma M, Dangi P, Choudhary M. Actinomycetes: source, identification, and their applications. Int J Curr Microbiol App Sci. 2014;3(2):801-32. doi: 10.20546/ ijcmas.2017.602.089

2. Anandan R, Dharumadurai D, Manogaran GP. An introduction to actinobacteria. Actinobacteria-Basics and Biotechnological Applications: IntechOpen. 2016.

3. Chaudhary HS, Yadav J, Shrivastava AR, Singh S, Singh AK, Gopalan N. Antibacterial activity of actinomycetes isolated from different soil samples of Sheopur (A city of central India). Journal of advanced pharmaceutical technology \& research. 2013;4(2):118. doi: $10.4103 / 2231-4040.111528$

4. Ganesan P, Reegan AD, David RHA, et al. Antimicrobial activity of some actinomycetes from Western Ghats of Tamil Nadu, India. Alexandria journal of medicine. 2017;53(2):101-10. doi: 10.1016/j.ajme.2016.03.004

5. Barka EA, Vatsa $P$, Sanchez L, et al. Taxonomy, physiology, and natural products of Actinobacteria. Microbiol. Mol. Biol. Rev. 2016;80(1):1-43. doi: 10.1128/MMBR.00019-15

6. Ludwig W, Euzéby J, Schumann $P$, et al. Road map of the phylum Actinobacteria. Bergey's manual ${ }^{\circledR}$ of systematic bacteriology: Springer, 2012:1-28. doi: 10.1007/978-0-387-68233-4_1

7. Kumar PS, Duraipandiyan V, Ignacimuthu S. Isolation, screening and partial purification of antimicrobial antibiotics from soil Streptomyces sp. SCA 7. The Kaohsiung journal of medical sciences. 2014;30(9):43546. doi: 10.1016/j.kjms.2014.05.006

8. Ahmad MS, El-Gendy AO, Ahmed RR, Hassan HM, ElKabbany HM, Merdash AG. Exploring the Antimicrobial and Antitumor Potentials of Streptomyces sp. AGM121 Isolated from Egyptian Soil. Frontiers in Microbiology. 2017;8(438). doi: 10.3389/fmicb.2017.00438

9. Goodfellow M, Williams S. Ecology of actinomycetes. Annual review of microbiology. 1983;37(1):189-216. doi: 10.1146/annurev.mi.37.100183.001201

10. Qin S, Li W-J, Klenk H-P, Hozzein WN, Ahmed I. Actinobacteria in Special and Extreme Habitats: Diversity, Function Roles and Environmental Adaptations. Frontiers in microbiology. 2019;10:944. doi: 10.3389/fmicb.2019.00944

11. Mukhtar S, Zaheer A, Aiysha D, Malik KA, Mehnaz S. Actinomycetes: a source of industrially important enzymes. J Proteomics Bioinform. 2017;10:12. doi: 10.4172/jpb.1000456

12. Prakash D, Nawani N, Prakash M, et al. Actinomycetes: a repertory of green catalysts with a potential revenue resource. BioMed research international. 2013;2013. doi: $10.1155 / 2013 / 264020$

13. Kamjam M, Sivalingam P, Deng Z, Hong K. Deep Sea Actinomycetes and Their Secondary Metabolites. Frontiers in Microbiology. 2017;8(760). doi: 10.3389/ fmicb. 2017.00760

14. Jakubiec-Krzesniak K, Rajnisz-Mateusiak A, Guspiel A, Ziemska J, Solecka J. Secondary metabolites of actinomycetes and their antibacterial, antifungal and antiviral properties. Pol. J. Microbiol. 2018;67:259-72. doi: 10.21307/pjm-2018-048

15. Harir M, Bendif $\mathrm{H}$, Bellahcene M, Fortas Z, Pogni R. Streptomyces Secondary Metabolites. Basic Biology and Applications of Actinobacteria. 2018:99. doi: 10.5772/intechopen.79890

16. Law JW-F, Pusparajah P, Ab Mutalib N-S, Wong SH, Goh $\mathrm{B}-\mathrm{H}$, Lee L-H. A Review on Mangrove Actinobacterial Diversity: The Roles of Streptomyces and Novel Species Discovery. Progress In Microbes \& Molecular Biology. 2019;1(1). doi: 10.36877/pmmb.a0000024

17. Ser H-L, Tan LT-H, Law JW-F, et al. Focused Review: Cytotoxic and Antioxidant Potentials of MangroveDerived Streptomyces. Frontiers in Microbiology. 2017;8(2065). doi: 10.3389/fmicb.2017.02065

18. Sakula A. Selman Waksman (1888-1973), discoverer of streptomycin: a centenary review. British journal of diseases of the chest. 1988;82:23-31. doi: 10.1016/0007-0971(88)90005-8

19. Waksman SA, Woodruff HB. The soil as a source of microorganisms antagonistic to disease-producing bacteria. Journal of bacteriology. 1940;40(4):581. doi: 10.1128/JB.40.4.581-600.1940

20. Waksman SA, Woodruff HB. Actinomyces antibioticus, a new soil organism antagonistic to pathogenic and non-pathogenic bacteria. Journal of bacteriology. 1941;42(2):231. doi: 10.1128/JB.42.2.231-249.1941 
21. Baltz RH. Renaissance in antibacterial discovery from actinomycetes. Current opinion in pharmacology. 2008;8(5):557-63. doi: 10.1016/j.coph.2008.04.008

22. Tiwari K, Gupta RK. Diversity and isolation of rare actinomycetes: an overview. Critical Reviews in Microbiology. 2013;39(3):256-94. doi: 10.3109/1040841X.2012.709819

23. Johnson CF, Curl EA, Bond JH, Fribourg HA. Methods for studying soil microflora-plant disease relationships. Burgess Publishing, Minneapolis 1959.

24. Küster $E$, Williams $S$. Selection of media for isolation of streptomycetes. Nature. 1964;202(4935):928. doi: 10.1038/202928a0

25. Miller GL. Use of dinitrosalicylic acid reagent for determination of reducing sugar. Analytical chemistry. 1959;31(3):426-28. doi: 10.1021/ac60147a030

26. Pathak N, Sanwal G. Multiple forms of polygalacturonase from banana fruits. Phytochemistry. 1998;48(2):24955. doi: 10.1016/S0031-9422(98)00005-3

27. Winkler UK, Stuckmann M. Glycogen, hyaluronate, and some other polysaccharides greatly enhance the formation of exolipase by Serratia marcescens. Journal of bacteriology. 1979;138(3):663-70. doi: 10.1128/ JB.138.3.663-670.1979

28. Al-Dhabi NA, Esmail GA, Duraipandiyan V, Arasu MV. Chemical profiling of Streptomyces sp. Al-Dhabi-2 recovered from an extreme environment in Saudi Arabia as a novel drug source for medical and industrial applications. Saudi journal of biological sciences.
2019;26(4):758-66. doi: 10.1016/j.sjbs.2019.03.009

29. Altschul SF, Gish W, Miller W, Myers EW, Lipman DJ. Basic local alignment search tool. Journal of molecular biology. 1990;215(3):403-10. doi: 10.1016/S00222836(05)80360-2

30. Mohamed H, Miloud B, Zohra F, Garcia-Arenzana $J M$, Veloso A, Rodriguez-Couto $S$. Isolation and Characterization of Actinobacteria from Algerian Sahara Soils with Antimicrobial Activities. Int J Mol Cell Med. 2017;6(2):109-20 doi: 10.22088/acadpub. BUMS.6.2.5

31. Yassien M, Asfour HZ. Production of Alpha-amylase by Streptomyces species isolated from west area of Saudi Arabia. J. Pharm. Res. 2011;4(12):4393-95

32. Salehghamari E, Nasrollahzadeh Z, Tahmaseb M, Amoozegar MA. Pectinase enzyme from Streptomyces coelicoflavus GIAL86 isolated from Meyghan Salt Lake, Arak, Iran. International Journal of Aquatic Biology. 2019;7(2):106-11

33. Cardenas F, Alvarez E, De Castro-Alvarez M, SánchezMontero J, Elson S, Sinisterra J. Three new lipases from actinomycetes and their use in organic reactions. Biocatalysis and Biotransformation. 2001;19(4):31529. doi: $10.3109 / 10242420109003647$

34. Swarna D, Gnanadoss JJ. Screening and Molecular Characterization of Actinomycetes from Mangrove Soil Producing Industrially Important Enzymes. Journal of Scientific Research. 2020;64(2). doi: 10.37398/ JSR.2020.640211 